\title{
Discovery Stories of RET Fusions in Lung Cancer: A Mini-Review
}

\author{
Kengo Takeuchi ${ }^{1,2 *}$ \\ 1 Division of Pathology, The Cancer Institute, Japanese Foundation for Cancer Research, Tokyo, Japan, ${ }^{2}$ Pathology Project \\ for Molecular Targets, The Cancer Institute, Japanese Foundation for Cancer Research, Tokyo, Japan
}

In 2004, a chemical inhibitor of the kinase activity of EGFR was reported to be effective in a subset of lung cancer patients with activating somatic mutations of EGFR. It remained unclear, however, whether kinase fusion genes also play a major role in the pathogenesis of lung cancers. The discovery of the EML4-ALK fusion kinase in 2007 was a breakthrough for this situation, and kinase fusion genes now form a group of relevant targetable oncogenes in lung cancer. In this mini-review article, the discovery of REarrangement during Transfection fusions, the third kinase fusion gene in lung cancer, is briefly described.

Keywords: ALK, RET, fusion gene, FISH, lung cancer

\section{OPEN ACCESS}

Edited by:

Masahide Takahashi,

Nagoya University, Japan

Reviewed by:

Takashi Kohno,

National Cancer Center Japan, Japan

Yasushi Yatabe,

Aichi Cancer Center, Japan

*Correspondence:

Kengo Takeuch

kentakeuchi-tky@umin.net

Specialty section:

This article was submitted to

Clinical and Translational Physiology,

a section of the journal

Frontiers in Physiology

Received: 26 September 2018

Accepted: 20 February 2019

Published: 19 March 2019

Citation:

Takeuchi K (2019) Discovery Stories of RET Fusions in Lung

Cancer: A Mini-Review.

Front. Physiol. 10:216.

doi: 10.3389/fphys.2019.00216

\section{INTRODUCTION}

Somatic mutations cause cancer via multiple mechanisms, including point mutations, insertions, deletions, and gene rearrangements. In non-small cell lung cancer (NSCLC), one of the most common causes of cancer-related deaths, these oncogenic mutations are usually mutually exclusive, and generally only a single major driver mutation is found in each case. In addition, such a cancer usually depends on the signal pathway stimulated by the principal oncogene for its survival (oncogene addiction) (Weinstein, 2002). In 2004, it was reported that a chemical inhibitor of the kinase activity of EGFR was effective in a subset of lung cancer patients with activating somatic mutations of EGFR (Lynch et al., 2004; Paez et al., 2004). NSCLC in which EGFR inhibitors are effective preferentially develop in Asian and non-smoker populations, generally lacking other targetable driver mutations (Paez et al., 2004; Pao et al., 2004; Shigematsu et al., 2005). In addition to EGFR mutations, kinase fusion genes have become a group of relevant oncogenes in NSCLC, because targeted inhibition of oncogenic kinase fusion proteins also leads to growth inhibition of the cancer cells and regression of the patient's tumor.

Gene fusion was known to be a major mechanism of oncogenesis in hematopoietic neoplasms and sarcomas (Mitelman, 2000). Various types of fusion oncogenes were reported (Mitelman et al., 2007) after the identification of the BCR-ABL1 fusion kinase in chronic myelogenous leukemia (Bartram et al., 1983). In contrast, it remained unclear for a long time whether such fusion oncogenes also play a major role in the pathogenesis of epithelial tumors. The discovery of the EML4-ALK fusion kinase in NSCLC via inv(2)(p21p23) was a breakthrough in this scenario (Soda et al., 2007). Moreover, several small molecules, such as crizotinib (Kwak et al., 2010; Shaw et al., 2013) and alectinib (Seto et al., 2013; Takeuchi et al., 2016; Hida et al., 2017), showed improved survival outcomes in ALK fusion-positive NSCLC patients. These clinical successes suggested that targeting specific fusion kinases was a promising strategy also for treating carcinomas (epithelial cancers). Representative fusions in epithelial tumors are listed in Table $\mathbf{1 .}$ 
Receptor tyrosine kinases including ALK usually comprise an extracellular receptor domain, a transmembrane domain, and an intracytoplasmic tyrosine kinase domain. The receptor domain binds to ligands, resulting in dimerization of the kinase protein. Then, the dimerized proteins are autophosphorylated and stimulate the RAS-MAPK-ERK and PI3K-AKT pathways to promote cell proliferation, migration, and differentiation. A receptor tyrosine kinase gene rearrangement gives rise to the expression of the fusion kinase protein if the $5^{\prime}$-partner gene fuses with the $3^{\prime}$-kinase gene in an in-frame fashion. These fusion kinases can be oncogenic when they retain the kinase domain and are dimerized through the $5^{\prime}$ partner, because this dimerization mimics that of the wild-type receptor tyrosine kinases through ligand binding. Consequently, a fusion kinase is constitutively expressed, dimerized, and autoactivated, and its downstream signaling promotes cell proliferation and survival.

\section{ALK FUSION}

ALK is a receptor tyrosine kinase that is not expressed in normal cells in adult mammals except for nerve cells. The most common mechanism of ALK overexpression and ALK kinase domain activation in neoplastic cells is the formation of a fusion protein with a partner through genomic rearrangement. In fact, ALK was first discovered in anaplastic large cell lymphoma (ALCL) in the form of a fusion protein, NPM1-ALK (Morris et al., 1994; Shiota et al., 1994). Other ALK fusion partners reported in ALCL are TFG, TPM3, TPM4, ATIC, RNF213, CLTC, MSN, MYH9, and TRAF (Hernandez et al., 1999; Lamant et al., 1999, 2003; Colleoni et al., 2000; Touriol et al., 2000; Meech et al., 2001; Tort et al., 2001; Cools et al., 2002; Feldman et al., 2013). NPM1-ALK is the most common ALK fusion in ALK-positive ALCL (70-80\%), followed by TPM3-ALK (12-18\%) (Tsuyama et al., 2017), and other fusions are rare. Except for ALCL, several hematopoietic neoplasms have been reported to have the following ALK fusion partners: CLTC, NPM1, SEC31A, SQSTM1, RANBP2, and EML4 in ALK-positive large B-cell lymphoma (Gascoyne et al., 2003; Van Roosbroeck et al., 2010; Takeuchi et al., 2011; Lee et al., 2014; Sakamoto et al., 2016); TPM3 in ALK-positive histiocytosis (Chan et al., 2008); and RANBP2 in myeloid leukemia (Maesako et al., 2014). In solid tumors, ALK fusions were identified in approximately $50 \%$ of inflammatory myofibroblastic tumor with the following fusion partners: TPM3, TPM4, CLTC, ATIC, CARS, SEC31A, RANBP2, PPFIBP1, FN1, TFG, EML4, LMNA, PRKAR1A, DCTN1, and RRBP1 (Lawrence et al., 2000; Bridge et al., 2001; Cools et al., 2002; Debelenko et al., 2003; DebiecRychter et al., 2003; Ma et al., 2003; Panagopoulos et al., 2006; Takeuchi et al., 2011; Lovly et al., 2014; Lee J.C. et al., 2017). Other ALK fusion-positive solid tumors include renal cancer (Debelenko et al., 2011; Marino-Enriquez et al., 2011; Sugawara et al., 2012; Kusano et al., 2016), colon cancer (Lin et al., 2009; Lipson et al., 2012; Stransky et al., 2014; Lee et al., 2015; Yakirevich et al., 2016), breast cancer (Lin et al., 2009), ovarian cancer (Ren et al., 2012), thyroid cancer (Cancer Genome Atlas Research Network, 2014; Kelly et al., 2014; McFadden et al., 2014; Perot et al., 2014; Stransky et al., 2014; Ji et al., 2015), and bladder
TABLE 1 | Representative fusion genes in epithelial tumors.

\begin{tabular}{|c|c|c|}
\hline & Fusion gene & Hisological type \\
\hline \multirow[t]{52}{*}{ Lung carcinoma } & $E M L 4-A L K$ & $\begin{array}{l}\text { Non-small cell } \\
\text { carcinoma }\end{array}$ \\
\hline & TFG-ALK & \\
\hline & KIF5B-ALK & \\
\hline & $K L C 1-A L K$ & \\
\hline & STRN-ALK & \\
\hline & TPR-ALK & \\
\hline & HIP1-ALK & \\
\hline & SEC31A-ALK & \\
\hline & BIRC6-ALK & \\
\hline & KIF5B-RET & \\
\hline & CCDC6-RET & \\
\hline & NCOA4-RET & \\
\hline & TRIM33-RET & \\
\hline & RUFY2-RET & \\
\hline & CUX1-RET & \\
\hline & KIAA1468-RET & \\
\hline & CD74-ROS1 & \\
\hline & SLC34A2-ROS1 & \\
\hline & SDC4-ROS1 & \\
\hline & EZR-ROS1 & \\
\hline & TPM3-ROS1 & \\
\hline & LRIG3-ROS1 & \\
\hline & GOPC (FIG)-ROS1 & \\
\hline & CCDC6-ROS1 & \\
\hline & MSN-ROS1 & \\
\hline & CD74-NTRK1 & \\
\hline & MPRIP-NTRK1 & \\
\hline & TPM3-NTRK1 & \\
\hline & TRIM24-NTRK2 & \\
\hline & BAG4-FGFR1 & \\
\hline & FGFR2-CIT & \\
\hline & FGFR2-KIAA1967 & \\
\hline & FGFR3-TACC3 & \\
\hline & FGFR3-BAIAP2L1 & \\
\hline & SCAF11-PDGFRA & \\
\hline & EZR-ERBB4 & \\
\hline & $A X L-M B I P$ & \\
\hline & TRIM4-BRAF & \\
\hline & TRIM24-BRAF & \\
\hline & SND1-BRAF & \\
\hline & CD74-NRG1 & \\
\hline & VAMP2-NRG1 & \\
\hline & SLC3A2-NRG1 & \\
\hline & MAP4KЗ-PRKCE & \\
\hline & BCASЗ-MAРЗКЗ & \\
\hline & ERBB2IP-MAST4 & \\
\hline & KRAS-CDH13 & \\
\hline & APLP2-TNFSF11 & \\
\hline & ZFYES-CGA & \\
\hline & TPD52L1-TRMT11 & \\
\hline & $E 2 A-P B X 1$ & \\
\hline & KIF5B-MET & \\
\hline
\end{tabular}

(Continued) 
TABLE 1 | Continued

\begin{tabular}{|c|c|c|}
\hline & Fusion gene & Hisological type \\
\hline & SPNS1-PRKCB & \\
\hline & WASF2-FGR & \\
\hline & ADCY9-PRKCB & \\
\hline \multirow[t]{19}{*}{ Thyroid carcinoma } & CCDC6(H4)-RET & Papillary carcinoma \\
\hline & TPM3-NTRK1 & \\
\hline & PRKAR1A-RET & \\
\hline & NCOA4(ELE1)-RET & \\
\hline & TFG-NTRK1 & \\
\hline & TPR-NTRK1 & \\
\hline & GOLGA5-RET & \\
\hline & TRIM24-RET & \\
\hline & TRIM33-RET & \\
\hline & $\begin{array}{l}\text { ERC1(RABGIP2)- } \\
\text { RET }\end{array}$ & \\
\hline & KTN1-RET & \\
\hline & RFG9-RET & \\
\hline & PCM1-RET & \\
\hline & RFP(TRIM27)-RET & \\
\hline & AKAP9-BRAF & \\
\hline & HOOKЗ-RET & \\
\hline & $E M L 4-A L K$ & \\
\hline & PAX8-PPARG & Follicular carcinoma \\
\hline & CREB3L2-PPARG & \\
\hline \multirow[t]{10}{*}{ Breast carcinoma } & ETV6-NTRK3 & $\begin{array}{l}\text { Secretary } \\
\text { carcinoma }\end{array}$ \\
\hline & $E M L 4-A L K$ & \\
\hline & ARID1A-MAST2 & \\
\hline & GPBP1L1-MAST2 & \\
\hline & ZNF700-MAST1 & \\
\hline & NFIX-MAST1 & \\
\hline & TADA2A-MAST1 & \\
\hline & SEC16A-NOTCH1 & \\
\hline & SEC22B-NOTCH2 & \\
\hline & MAG/3-AKT3 & \\
\hline \multirow[t]{4}{*}{ Gastric carcinoma } & AGTRAP-BRAF & \\
\hline & CD44-SLC1A2 & \\
\hline & $\begin{array}{l}\text { CLDN18- } \\
\text { ARHGAP26 }\end{array}$ & \\
\hline & SLC34A2-ROS1 & \\
\hline \multirow[t]{3}{*}{ Colorectal carcinoma } & TPM3-NTRK1 & \\
\hline & $E M L 4-A L K$ & \\
\hline & C2orf44-ALK & \\
\hline \multirow[t]{11}{*}{ Prostate carcinoma } & TMPRSS2-ERG & \\
\hline & SLC45A3-ERG & \\
\hline & HERPUD1-ERG & \\
\hline & NDRG1-ERG & \\
\hline & SLC45A3-ELK4 & \\
\hline & TMPRSS2-ETV1 & \\
\hline & SLC45A3-ETV1 & \\
\hline & HERVK-ETV1 & \\
\hline & C15orf21-ETV1 & \\
\hline & HNRPA2B1-ETV1 & \\
\hline & ACSL3-ETV1 & \\
\hline
\end{tabular}

(Continued)
TABLE 1 | Continued

\begin{tabular}{|c|c|c|}
\hline & Fusion gene & Hisological type \\
\hline & EST14-ETV1 & \\
\hline & $\begin{array}{l}\text { HERVK17(FLJ35294)- } \\
\text { ETV1 }\end{array}$ & \\
\hline & FOXP1-ETV1 & \\
\hline & TMPRSS2-ETV4 & \\
\hline & DDX5-ETV4 & \\
\hline & CANT1-ETV4 & \\
\hline & KLK2-ETV4 & \\
\hline & TMPRSS2-ETV5 & \\
\hline & SLC45A3-ETV5 & \\
\hline & ESRP1-RAF1 & \\
\hline & RAF1-ESRP1 & \\
\hline & SLC45A3-BRAF & \\
\hline \multirow[t]{11}{*}{ Renal cell carcinoma } & PRCC-TFE3 & $\begin{array}{l}\text { Xp11.2 } \\
\text { translocation renal } \\
\text { cell carcinoma }\end{array}$ \\
\hline & SFPQ-TFE3 & \\
\hline & NonO-TFE3 & \\
\hline & ASPSCR1-TFE3 & \\
\hline & CLTC-TFE3 & \\
\hline & $t(3 ; X)(q 23 ; p 11.23)$ & \\
\hline & $\begin{array}{l}\text { Alpha(MALAT1)- } \\
\text { TFEB }\end{array}$ & \\
\hline & $V C L-A L K$ & \\
\hline & $E M L 4-A L K$ & \\
\hline & TPM3-ALK & \\
\hline & STRN-ALK & \\
\hline \multirow[t]{2}{*}{ Bladder carcinoma } & FGFRЗ-TACCЗ & $\begin{array}{l}\text { Urothelial } \\
\text { carcinoma }\end{array}$ \\
\hline & FGFR3-BAIAP2L 1 & \\
\hline \multirow[t]{14}{*}{ Salivary gland tumor } & CTNNB1-PLAG1 & $\begin{array}{l}\text { Pleomorphic } \\
\text { adenoma }\end{array}$ \\
\hline & LIFR-PLAG1 & \\
\hline & TCEA1-PLAG1 & \\
\hline & HMGA2-FHIT & \\
\hline & HMGA2-NFIB & \\
\hline & CHCHD7-PLAG1 & \\
\hline & HMGA2-WIF1 & \\
\hline & ETV6-NTRK3 & $\begin{array}{l}\text { Secretory } \\
\text { carcinoma }\end{array}$ \\
\hline & CRTC1-MAML2 & $\begin{array}{l}\text { Mucoepidermoid } \\
\text { carcinoma }\end{array}$ \\
\hline & CRTC3-MAML2 & \\
\hline & EWSR1-ATF1 & $\begin{array}{l}\text { Clear cell } \\
\text { carcinoma }\end{array}$ \\
\hline & EWSR1-CREM & \\
\hline & MYB-NFIB & $\begin{array}{l}\text { Adenoid cytic } \\
\text { carcinoma }\end{array}$ \\
\hline & MYBL1-NFIB & \\
\hline
\end{tabular}

cancer (Stransky et al., 2014). The frequencies are 1-2\% in thyroid cancer (Cancer Genome Atlas Research Network, 2014; Kelly et al., 2014; McFadden et al., 2014; Ji et al., 2015) and less than $1 \%$ in kidney and colon cancers (Sugawara et al., 2012; Yakirevich et al., 2016). In NSCLC, EML4 is the most common partner of 
ALK. Although very rare, KIF5B, KLC1, TFG, STRN, PTPN3, HIP1, TPR, SEC31A, SQSTM1, DCTN1, and CRIM1 were also reported as an ALK fusion partner (Rikova et al., 2007; Takeuchi et al., 2009; Jung et al., 2012; Togashi et al., 2012; Majewski et al., 2013; Choi et al., 2014; Hong et al., 2014; Iyevleva et al., 2015; Kim et al., 2016; Tan et al., 2016).

\section{RET FUSION}

REarrangement during Transfection (RET) was identified by Takahashi et al. in 1985 as a proto-oncogene that underwent rearrangement during the transfection of DNA extracted from human T-cell lymphoma into NIH-3T3 cells (Takahashi et al., 1985). RET is a receptor tyrosine kinase encoded by a gene located on 10q11.22 (Ishizaka et al., 1989), and physiologically plays an important role in the development of neurons and kidneys. The first RET fusion in human cancer samples, CCDC6-RET, was identified in papillary thyroid carcinoma by Grieco et al. (1990). RET fusions are detected in $13-43 \%$ of papillary thyroid carcinomas (Kondo et al., 2006), and at least 12 RET fusions have been reported so far (Table 2).

\section{DISCOVERY OF RET FUSIONS IN LUNG CANCER}

In 2012, the first RET fusion in lung cancer, KIF5B-RET, was reported independently by 4 groups from Korea (Ju et al., 2012), Japan (2 groups) (Kohno et al., 2012; Takeuchi et al., 2012), and the United States (Lipson et al., 2012). Ju et al. (2012) examined tissue and peripheral blood samples from a 33-yearold Korean never-smoking male with lung adenocarcinoma. The patient was negative for EGFR and KRAS mutations, and the $E M L 4-A L K$ fusion gene, which were the three well-known driver mutations in lung adenocarcinoma at that time. Fiftytwo fusion transcripts were called by transcriptome analysis in the patient's adenocarcinoma. Out of 52 fusions, they could detect a corresponding genomic rearrangement only for KIF5BRET fusion (KIF5B exon 16;RET exon 12 fusion variant.

TABLE 2 | RET fusions in thyroid cancer.

\begin{tabular}{lcl}
\hline RET fusion & Locus of the partner gene & Reference \\
\hline CCDC6(H4)-RET & $10 q 21.2$ & Grieco et al., 1990 \\
PRKAR1A-RET & $17 q 24.2$ & Bongarzone et al., 1993 \\
NCOA4(ELE1)-RET & $10 q 11.23$ & Bongarzone et al., 1994 \\
GOLGA5-RET & $14 q 32.12$ & Klugbauer and Rabes, 1999 \\
TRIM24-RET & $7 q 33-34$ & Klugbauer and Rabes, 1999 \\
TRIM33-RET & $1 p 13.2$ & \\
ERC1(RAB6IP2)-RET & $12 p 13.33$ & Nakata et al., 1999 \\
KTN1-RET & $14 q 22.3$ & Salassidis et al., 2000 \\
RFG9-RET & $18 q 21-22$ & Klugbauer et al., 2000 \\
PCM1-RET & $8 q 21-22$ & Corvi et al., 2000 \\
RFP(TRIM27)-RET & $6 p 22.1$ & Saenko et al., 2003 \\
HOOK3-RET & $8 p 11.21$ & Ciampi et al., 2007
\end{tabular}

K16;R12) by whole genome sequencing. Additionally, they performed transcriptome analysis in 5 lung adenocarcinomas that were negative for EGFR and KRAS mutations and EML4$A L K$, and identified one more case with KIF5B-RET fusion transcript (K15;R12). Furthermore, they found another KIF5BRET-positive case (K23;R12) in 15 "double-negative (negative for EGFR mutation and EML4-ALK but KRAS status unknown)" lung adenocarcinomas by RT-PCR. Based on their detection rate, they estimated that the fusion might exist in approximately $6 \%$ of lung adenocarcinomas.

The following three studies were published in the same issue of the same journal, reflecting the "fusion kinase discovery race in major carcinomas" in those days. In the three studies, the frequency and oncogenicity of KIF5B-RET were more specifically evidenced, and growth inhibition analyses using cell lines and RET inhibitors were performed. Kohno et al. (2012) at the National Cancer Center researchers in Japan performed whole-transcriptome sequencing of 30 lung adenocarcinomas to identify new fusion genes that could be targeted for therapy. As a result, they discovered a KIF5BRET fusion transcript in 1 out of 30 cases. In addition, 289 Japanese lung adenocarcinomas were screened by RTPCR and Sanger sequence analyses, and the KIF5B-RET fusion gene was identified in 5 cases. In total, they identified 6 KIF5B-RET-positive cases out of 319 lung adenocarcinomas (1.9\%), and 4 fusion variants in these 6 tumors. They also examined lung adenocarcinomas in the United States and Norway, and detected a KIF5B-RET transcript in one of the $80(1.3 \%)$ subjects from the United States, but not in the 34 from Norway. They exogenously expressed a KIF5B-RET transcript (KIF5B exon 15;RET exon 12 variant. $\mathrm{K} 15 ; \mathrm{R} 12)$ in the H1299 human lung cancer cell line and showed that Tyr905 was phosphorylated in the absence of serum stimulation. This phosphorylation was suppressed by vandetanib, a tyrosine kinase inhibitor to several receptor tyrosine kinases, including RET. They also showed that expression of exogenous KIF5B-RET induced morphological transformation and anchorage-independent growth of NIH-3T3 cells, which was suppressed by vandetanib.

Lipson et al. (2012) analyzed genomic DNA extracted from 24 formalin-fixed paraffin-embedded (FFPE) specimens of NSCLC by capture sequencing targeting 2,574 coding exons of 145 cancer-relevant genes and 37 introns of 14 frequently rearranged genes in cancer. They identified a KIF5B-RET transcript (K15;R12), generated via an 11,294,741-bp pericentric inversion on chromosome 10 in a lung adenocarcinoma from a 44-year-old never-smoking man of European ancestry. They detected KIF5B-RET fusions by RT-PCR in 1 of $121(0.8 \%)$ European-ancestry and 9 of 405 (2\%) Asian subjects, all of whom were never or limited former smokers. They estimated an overall occurrence rate of $2.0 \%$ (95\% CI 0.8-3.1\%). Four transcript variants were reported by them: K15;R12, K16;R12, $\mathrm{K} 22 ; \mathrm{R} 12$, and $\mathrm{K} 15 ; \mathrm{R} 11 . \mathrm{Ba} / \mathrm{F} 3$ cells, which are dependent on interleukin-3 (IL-3) for growth, that expressed KIF5B-RET were transformed and lived without IL-3. The cells were sensitive to sunitinib, sorafenib, and vandetanib, which are multi-target kinase inhibitors that inhibit RET. 


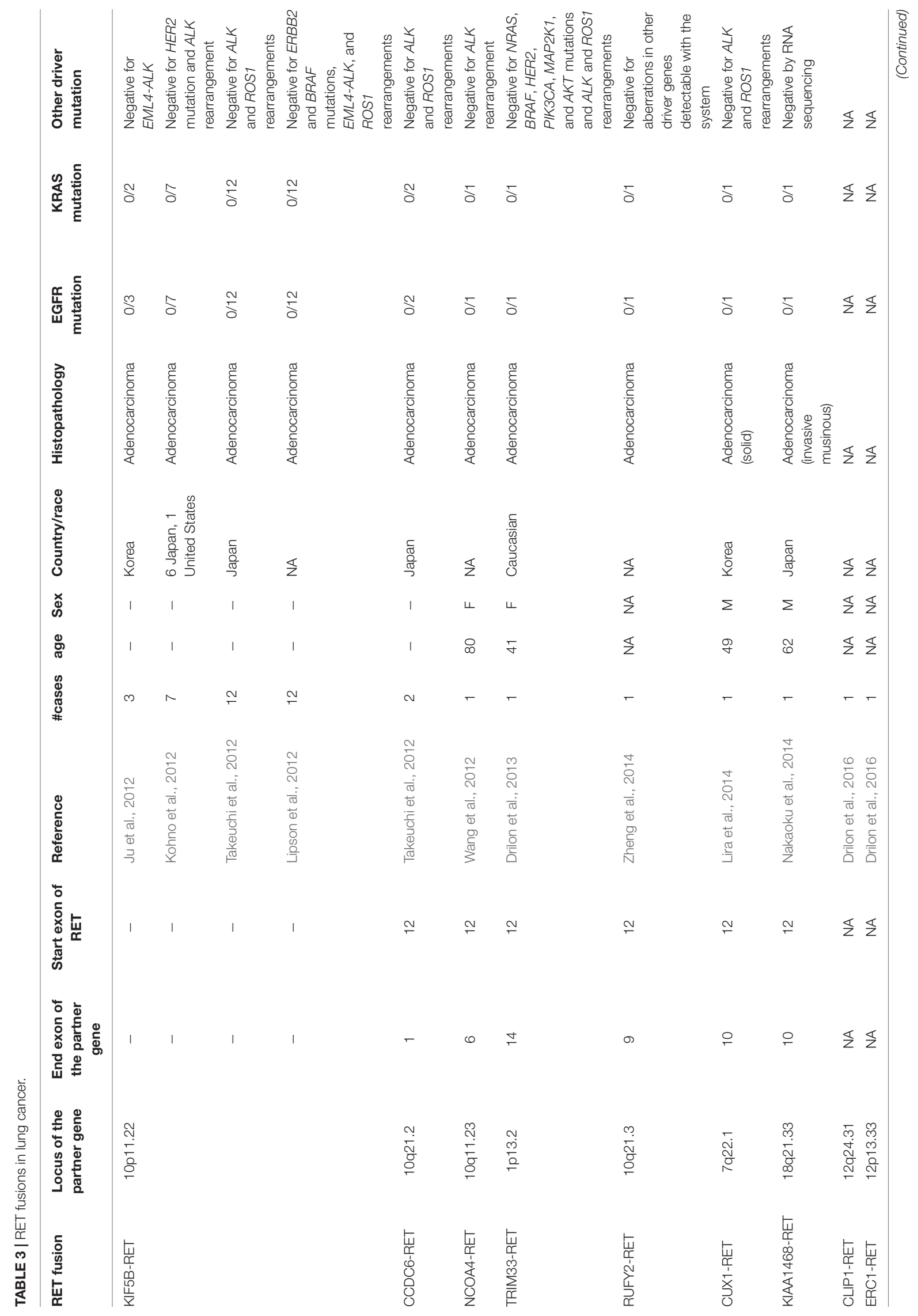




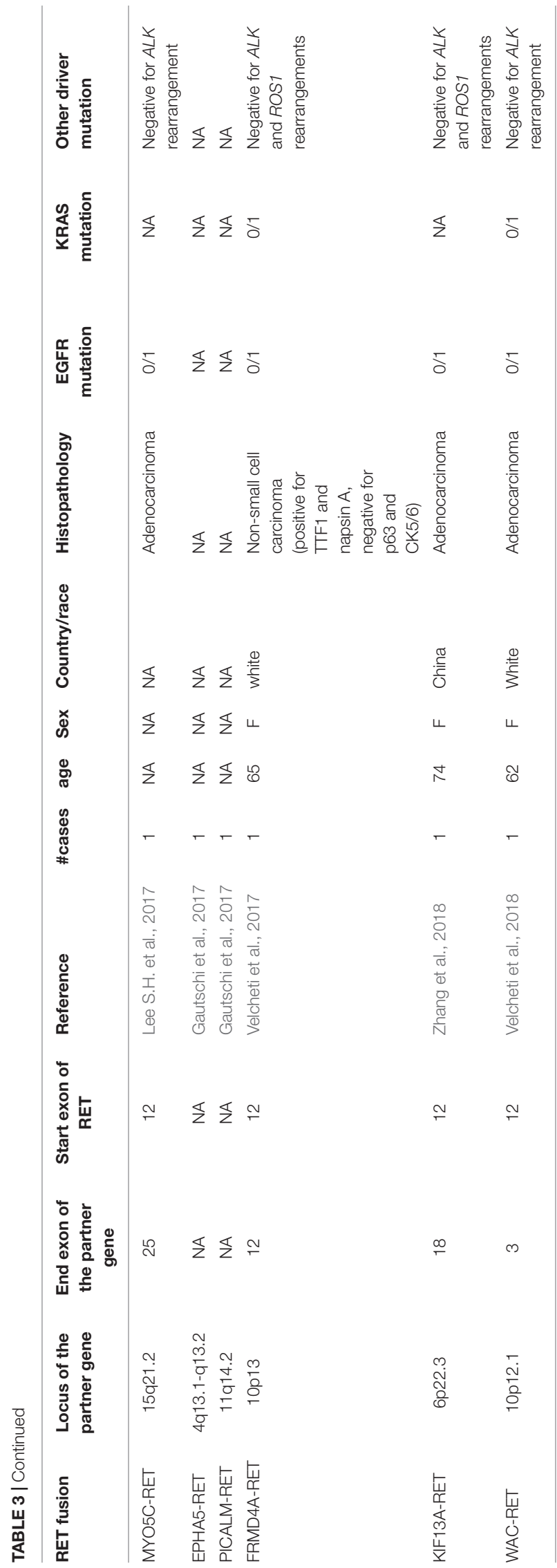

Unlike the above-mentioned three studies, Takeuchi et al. (2012) identified KIF5B-RET fusions without nextgeneration sequencing analyses, but with traditional methods. They established an integrated platform of conventional histopathology and molecular pathology to identify fusion genes in various types of cancer. They performed fluorescence in situ hybridization (FISH) with their laboratory-made probes on tissue microarrays of various types of cancers. Using lung cancer tissue microarrays containing 1,528 samples, rearrangement of KIF5B was examined by a split FISH assay to discover new fusions, because they previously identified KIF5B-ALK fusions in lung cancer (Takeuchi et al., 2009) and thus hypothesized that KIF5B might fuse to other kinases in lung cancer. Twentyfour KIF5B split FISH-positive tumors were identified; among them, a KIF5B-RET transcript $(\mathrm{K} 23 ; \mathrm{R} 12)$ was identified by $3^{\prime}$ rapid amplification of cDNA ends (RACE). Then, 22 RET rearrangement-positive tumors were identified in 1,528 lung cancers by RET split FISH. Among the 22 cases, 12 KIF5B-RETpositive tumors were identified through a multiplex RT-PCR system that captures all possible KIF5B-RET fusions: 8 cases with $\mathrm{K} 15 ; \mathrm{R} 12$, and one case each with the K16;R12, K22;R12, $\mathrm{K} 23 ; \mathrm{R} 12$, and $\mathrm{K} 24 ; \mathrm{R} 11$. The presence of inv(10)(p11.22q11.2) was supported by a KIF5B-RET fusion FISH assay in all 12 of these tumors. In lung cancer, they also identified CCDC6-RET, which is the first RET fusion identified in thyroid cancer (Grieco et al., 1990). In a routine pathology diagnosis during the study period, a pathologist in the group encountered an adenocarcinoma with a mucinous cribriform pattern that is a histopathological marker for the presence of EML4-ALK (Inamura et al., 2008). The case was, however, negative for ALK fusion and was positive for CCDC6-RET, as determined by FISH and inverse RT-PCR. In the remaining 10 tumors, another CCDC6-RET-positive tumor was identified by RT-PCR. In total, 14 RET fusion-positive tumors (13 out of the 1,528 tumors tested, and one additional tumor found through a routine pathology diagnostic service) were identified. RET fusions existed in $0.9 \%$ (13 out of 1,482) of the NSCLCs and $1.2 \%$ (13 out of 1,119$)$ of the adenocarcinomas. The researchers demonstrated the oncogenicity of all the 5 KIF5B-RET fusion variants they identified through a focus formation assay and a mouse subcutaneous transplantation assay using NIH-3T3 cells expressing each KIF5B-RET variant. KIF5B-RET (K15;R12) transfected $\mathrm{Ba} / \mathrm{F} 3$ cells grew in the absence of IL-3. Vandetanib inhibited the proliferation of cells expressing K15;R12 but not the proliferation of cells expressing EML4-ALK.

To date, at least 15 RET fusions have been reported in NSCLC including KIF5B-RET (Ju et al., 2012; Kohno et al., 2012; Lipson et al., 2012; Takeuchi et al., 2012), CCDC6-RET (Takeuchi et al., 2012), NCOA4-RET (Wang et al., 2012), TRIM33-RET (Drilon et al., 2013), RUFY2-RET (Zheng et al., 2014), CUX1-RET (Lira et al., 2014), KIAA1468-RET (Nakaoku et al., 2014), CLIP1RET (Drilon et al., 2016), ERC1-RET (Drilon et al., 2016), MYO5C-RET (Lee S.H. et al., 2017), EPHA5-RET (Gautschi et al., 2017), PICALM-RET (Gautschi et al., 2017), FRMD4ARET (Velcheti et al., 2017), KIF13A-RET (Zhang et al., 2018), and WAC-RET (Velcheti et al., 2018; Table 3). Most cases of RET fusion-positive NSCLCs are adenocarcinoma, although some authors reported non-adenocarcinoma cases including 
adenosquamous cell carcinoma (Wang et al., 2012; Song et al., 2017) and squamous cell carcinoma (Cai et al., 2013). In RET fusion-positive adenocarcinomas, specific histological features were not identified, although several characteristic features like cytoplasmic mucin production were detected (Tsuta et al., 2014). Driver mutations in other genes including EGFR, KRAS, HER2, $B R A F, A L K$, and ROS1 are rare.

\section{CONCLUDING REMARKS}

REarrangement during Transfection-positive lung cancers constitute a small subset of lung adenocarcinomas showing clinicopathological features similar to those of other fusion kinase-positive lung cancers. Since their discovery, several trials for RET-positive lung cancer have been conducted using

\section{REFERENCES}

Bartram, C. R., de Klein, A., Hagemeijer, A., van Agthoven, T., Geurts van Kessel, A., Bootsma, D., et al. (1983). Translocation of c-abl oncogene correlates with the presence of a Philadelphia chromosome in chronic myelocytic leukaemia. Nature 306, 277-280. doi: 10.1038/306277a0

Bongarzone, I., Butti, M. G., Coronelli, S., Borrello, M. G., Santoro, M., Mondellini, P., et al. (1994). Frequent activation of ret protooncogene by fusion with a new activating gene in papillary thyroid carcinomas. Cancer Res. 54, 2979-2985.

Bongarzone, I., Monzini, N., Borrello, M. G., Carcano, C., Ferraresi, G., Arighi, E., et al. (1993). Molecular characterization of a thyroid tumor-specific transforming sequence formed by the fusion of ret tyrosine kinase and the regulatory subunit RI alpha of cyclic AMP-dependent protein kinase A. Mol. Cell Biol. 13, 358-366.

Bridge, J. A., Kanamori, M., Ma, Z., Pickering, D., Hill, D. A., Lydiatt, W., et al. (2001). Fusion of the ALK gene to the clathrin heavy chain gene, CLTC, in inflammatory myofibroblastic tumor. Am. J. Pathol. 159, 411-415. doi: 10.1016/ S0002-9440(10)61711-7

Cai, W., Su, C., Li, X., Fan, L., Zheng, L., Fei, K., et al. (2013). KIF5B-RET fusions in Chinese patients with non-small cell lung cancer. Cancer 119, 1486-1494. doi: $10.1002 / \mathrm{cncr} .27940$

Cancer Genome Atlas Research Network (2014). Integrated genomic characterization of papillary thyroid carcinoma. Cell 159, 676-690. doi: 10.1016/j.cell.2014.09.050

Chan, J. K., Lamant, L., Algar, E., Delsol, G., Tsang, W. Y., Lee, K. C., et al. (2008). ALK+ histiocytosis: a novel type of systemic histiocytic proliferative disorder of early infancy. Blood 112, 2965-2968. doi: 10.1182/blood-2008-03-147017

Choi, Y. L., Lira, M. E., Hong, M., Kim, R. N., Choi, S. J., Song, J. Y., et al. (2014). A novel fusion of TPR and ALK in lung adenocarcinoma. J. Thorac. Oncol. 9, 563-566. doi: 10.1097/JTO.0000000000000093

Ciampi, R., Giordano, T. J., Wikenheiser-Brokamp, K., Koenig, R. J., and Nikiforov, Y. E. (2007). HOOK3-RET: a novel type of RET/PTC rearrangement in papillary thyroid carcinoma. Endocr. Relat. Cancer 14, 445-452. doi: 10.1677/ ERC-07-0039

Colleoni, G. W., Bridge, J. A., Garicochea, B., Liu, J., Filippa, D. A., and Ladanyi, M. (2000). ATIC-ALK: a novel variant ALK gene fusion in anaplastic large cell lymphoma resulting from the recurrent cryptic chromosomal inversion, inv(2)(p23q35). Am. J. Pathol. 156, 781-789. doi: 10.1016/S0002-9440(10) 64945-0

Cools, J., Wlodarska, I., Somers, R., Mentens, N., Pedeutour, F., Maes, B., et al. (2002). Identification of novel fusion partners of ALK, the anaplastic lymphoma kinase, in anaplastic large-cell lymphoma and inflammatory myofibroblastic tumor. Genes Chromosomes Cancer 34, 354-362. doi: 10.1002/gcc.10033

Corvi, R., Berger, N., Balczon, R., and Romeo, G. (2000). RET/PCM-1: a novel fusion gene in papillary thyroid carcinoma. Oncogene 19, 4236-4242. doi: 10. 1038/sj.onc. 1203772 kinase inhibitors including vandetanib, cabozantinib, sorafenib, sunitinib, lenvatinib, ponatinib, and dovitinib. Although some clinical benefits were observed, efficacy was limited compared with that shown by EGFR and ALK inhibitors. The abovementioned agents used in earlier trials are multi-kinase inhibitors, and are notably more effective to VEGFR, EGFR, and KIT than RET. Therefore, off-target dose limiting toxicity caused frequent dose reduction and discontinuation. RET inhibitors with more specificity and hence less off-target toxicity are currently undergoing clinical and preclinical development.

\section{AUTHOR CONTRIBUTIONS}

The author confirms being the sole contributor of this work and has approved it for publication.

Debelenko, L. V., Arthur, D. C., Pack, S. D., Helman, L. J., Schrump, D. S., and Tsokos, M. (2003). Identification of CARS-ALK fusion in primary and metastatic lesions of an inflammatory myofibroblastic tumor. Lab. Invest. 83, 1255-1265. doi: 10.1097/01.LAB.0000088856.49388.EA

Debelenko, L. V., Raimondi, S. C., Daw, N., Shivakumar, B. R., Huang, D., Nelson, M., et al. (2011). Renal cell carcinoma with novel VCL-ALK fusion: new representative of ALK-associated tumor spectrum. Mod. Pathol. 24, 430-442. doi: $10.1038 /$ modpathol.2010.213

Debiec-Rychter, M., Marynen, P., Hagemeijer, A., and Pauwels, P. (2003). ALKATIC fusion in urinary bladder inflammatory myofibroblastic tumor. Genes Chromosomes Cancer 38, 187-190. doi: 10.1002/gcc.10267

Drilon, A., Rekhtman, N., Arcila, M., Wang, L., Ni, A., Albano, M., et al. (2016). Cabozantinib in patients with advanced RET-rearranged non-small-cell lung cancer: an open-label, single-centre, phase 2, single-arm trial. Lancet Oncol. 17, 1653-1660. doi: 10.1016/S1470-2045(16)30562-9

Drilon, A., Wang, L., Hasanovic, A., Suehara, Y., Lipson, D., Stephens, P., et al. (2013). Response to Cabozantinib in patients with RET fusion-positive lung adenocarcinomas. Cancer Discov. 3, 630-635. doi: 10.1158/2159-8290.CD-130035

Feldman, A. L., Vasmatzis, G., Asmann, Y. W., Davila, J., Middha, S., Eckloff, B. W., et al. (2013). Novel TRAF1-ALK fusion identified by deep RNA sequencing of anaplastic large cell lymphoma. Genes Chromosomes Cancer 52, 1097-1102. doi: $10.1002 /$ gcc. 22104

Gascoyne, R. D., Lamant, L., Martin-Subero, J. I., Lestou, V. S., Harris, N. L., Muller-Hermelink, H. K., et al. (2003). ALK-positive diffuse large B-cell lymphoma is associated with Clathrin-ALK rearrangements: report of 6 cases. Blood 102, 2568-2573. doi: 10.1182/blood-2003-03-0786

Gautschi, O., Milia, J., Filleron, T., Wolf, J., Carbone, D. P., Owen, D., et al. (2017). Targeting RET in patients with RET-rearranged lung cancers: results from the global, multicenter RET registry. J. Clin. Oncol. 35, 1403-1410. doi: 10.1200/JCO.2016.70.9352

Grieco, M., Santoro, M., Berlingieri, M. T., Melillo, R. M., Donghi, R., Bongarzone, I., et al. (1990). PTC is a novel rearranged form of the ret proto-oncogene and is frequently detected in vivo in human thyroid papillary carcinomas. Cell 60, 557-563. doi: 10.1016/0092-8674(90)90659-3

Hernandez, L., Pinyol, M., Hernandez, S., Bea, S., Pulford, K., Rosenwald, A., et al. (1999). TRK-fused gene (TFG) is a new partner of ALK in anaplastic large cell lymphoma producing two structurally different TFG-ALK translocations. Blood 94, 3265-3268.

Hida, T., Nokihara, H., Kondo, M., Kim, Y. H., Azuma, K., Seto, T., et al. (2017). Alectinib versus crizotinib in patients with ALK-positive non-small-cell lung cancer (J-ALEX): an open-label, randomised phase 3 trial. Lancet 390, 29-39. doi: 10.1016/S0140-6736(17)30565-2

Hong, M., Kim, R. N., Song, J. Y., Choi, S. J., Oh, E., Lira, M. E., et al. (2014). HIP1-ALK, a novel fusion protein identified in lung adenocarcinoma. J. Thorac. Oncol. 9, 419-422. doi: 10.1097/JTO.0000000000 000061 
Inamura, K., Takeuchi, K., Togashi, Y., Nomura, K., Ninomiya, H., Okui, M., et al. (2008). EML4-ALK fusion is linked to histological characteristics in a subset of lung cancers. J. Thorac. Oncol. 3, 13-17. doi: 10.1097/JTO.0b013e31815e8b60

Ishizaka, Y., Itoh, F., Tahira, T., Ikeda, I., Sugimura, T., Tucker, J., et al. (1989). Human ret proto-oncogene mapped to chromosome 10q11.2. Oncogene 4, 1519-1521.

Iyevleva, A. G., Raskin, G. A., Tiurin, V. I., Sokolenko, A. P., Mitiushkina, N. V., Aleksakhina, S. N., et al. (2015). Novel ALK fusion partners in lung cancer. Cancer Lett. 362, 116-121. doi: 10.1016/j.canlet.2015.03.028

Ji, J. H., Oh, Y. L., Hong, M., Yun, J. W., Lee, H. W., Kim, D., et al. (2015). Identification of driving ALK fusion genes and genomic landscape of medullary thyroid cancer. PLoS Genet. 11:e1005467. doi: 10.1371/journal.pgen. 1005467

Ju, Y. S., Lee, W. C., Shin, J. Y., Lee, S., Bleazard, T., Won, J. K., et al. (2012). A transforming KIF5B and RET gene fusion in lung adenocarcinoma revealed from whole-genome and transcriptome sequencing. Genome Res. 22, 436-445. doi: 10.1101/gr.133645.111

Jung, Y., Kim, P., Jung, Y., Keum, J., Kim, S. N., Choi, Y. S., et al. (2012). Discovery of ALK-PTPN3 gene fusion from human non-small cell lung carcinoma cell line using next generation RNA sequencing. Genes Chromosomes Cancer 51, 590-597. doi: 10.1002/gcc. 21945

Kelly, L. M., Barila, G., Liu, P., Evdokimova, V. N., Trivedi, S., Panebianco, F., et al. (2014). Identification of the transforming STRN-ALK fusion as a potential therapeutic target in the aggressive forms of thyroid cancer. Proc. Natl. Acad. Sci. U.S.A. 111, 4233-4238. doi: 10.1073/pnas.1321937111

Kim, R. N., Choi, Y. L., Lee, M. S., Lira, M. E., Mao, M., Mann, D., et al. (2016). SEC31A-ALK fusion gene in lung adenocarcinoma. Cancer Res. Treat. 48, 398-402. doi: 10.4143/crt.2014.254

Kohno, T., Ichikawa, H., Totoki, Y., Yasuda, K., Hiramoto, M., Nammo, T., et al. (2012). KIF5B-RET fusions in lung adenocarcinoma. Nat. Med. 18, 375-377. doi: $10.1038 / \mathrm{nm} .2644$

Kondo, T., Ezzat, S., and Asa, S. L. (2006). Pathogenetic mechanisms in thyroid follicular-cell neoplasia. Nat. Rev. Cancer 6, 292-306. doi: 10.1038/ nrc1836

Klugbauer, S., Demidchik, E. P., Lengfelder, E., and Rabes, H. M. (1998). Detection of a novel type of RET rearrangement (PTC5) in thyroid carcinomas after Chernobyl and analysis of the involved RET-fused gene RFG5. Cancer Res. 58, 198-203.

Klugbauer, S., Jauch, A., Lengfelder, E., Demidchik, E., and Rabes, H. M. (2000). A novel type of RET rearrangement (PTC8) in childhood papillary thyroid carcinomas and characterization of the involved gene (RFG8). Cancer Res. 60, 7028-7032.

Klugbauer, S., and Rabes, H. M. (1999). The transcription coactivator HTIF1 and a related protein are fused to the RET receptor tyrosine kinase in childhood papillary thyroid carcinomas. Oncogene 18, 4388-4393. doi: 10.1038/sj.onc. 1202824

Kusano, H., Togashi, Y., Akiba, J., Moriya, F., Baba, K., Matsuzaki, N., et al. (2016). Two cases of renal cell carcinoma harboring a novel STRN-ALK fusion gene. Am. J. Surg. Pathol. 40, 761-769. doi: 10.1097/PAS.0000000000000610

Kwak, E. L., Bang, Y. J., Camidge, D. R., Shaw, A. T., Solomon, B., Maki, R. G., et al. (2010). Anaplastic lymphoma kinase inhibition in non-small-cell lung cancer. N. Engl. J. Med. 363, 1693-1703. doi: 10.1056/NEJMoa1006448

Lamant, L., Dastugue, N., Pulford, K., Delsol, G., and Mariame, B. (1999). A new fusion gene TPM3-ALK in anaplastic large cell lymphoma created by a $(1 ; 2)(\mathrm{q} 25 ; \mathrm{p} 23)$ translocation. Blood 93, 3088-3095.

Lamant, L., Gascoyne, R. D., Duplantier, M. M., Armstrong, F., Raghab, A., Chhanabhai, M., et al. (2003). Non-muscle myosin heavy chain (MYH9): a new partner fused to ALK in anaplastic large cell lymphoma. Genes Chromosomes Cancer 37, 427-432. doi: 10.1002/gcc.10232

Lawrence, B., Perez-Atayde, A., Hibbard, M. K., Rubin, B. P., Dal Cin, P., Pinkus, J. L., et al. (2000). TPM3-ALK and TPM4-ALK oncogenes in inflammatory myofibroblastic tumors. Am. J. Pathol. 157, 377-384. doi: 10.1016/S00029440(10)64550-6

Lee, J., Kim, H. C., Hong, J. Y., Wang, K., Kim, S. Y., Jang, J., et al. (2015). Detection of novel and potentially actionable anaplastic lymphoma kinase (ALK) rearrangement in colorectal adenocarcinoma by immunohistochemistry screening. Oncotarget 6, 24320-24332. doi: 10.18632/oncotarget.4462

Lee, J. C., Li, C. F., Huang, H. Y., Zhu, M. J., Marino-Enriquez, A., Lee, C. T., et al. (2017). ALK oncoproteins in atypical inflammatory myofibroblastic tumours: novel RRBP1-ALK fusions in epithelioid inflammatory myofibroblastic sarcoma. J. Pathol. 241, 316-323. doi: 10.1002/path.4836

Lee, S. E., Kang, S. Y., Takeuchi, K., and Ko, Y. H. (2014). Identification of RANBP2-ALK fusion in ALK positive diffuse large B-cell lymphoma. Hematol. Oncol. 32, 221-224. doi: 10.1002/hon.2125

Lee, S. H., Lee, J. K., Ahn, M. J., Kim, D. W., Sun, J. M., Keam, B., et al. (2017). Vandetanib in pretreated patients with advanced non-small cell lung cancerharboring RET rearrangement: a phase II clinical trial. Ann. Oncol. 28, 292-297. doi: 10.1093/annonc/mdw559

Lin, E., Li, L., Guan, Y., Soriano, R., Rivers, C. S., Mohan, S., et al. (2009). Exon array profiling detects EML4-ALK fusion in breast, colorectal, and non-small cell lung cancers. Mol. Cancer Res. 7, 1466-1476. doi: 10.1158/1541-7786.MCR08-0522

Lipson, D., Capelletti, M., Yelensky, R., Otto, G., Parker, A., Jarosz, M., et al. (2012). Identification of new ALK and RET gene fusions from colorectal and lung cancer biopsies. Nat. Med. 18, 382-384. doi: 10.1038/nm.2673

Lira, M. E., Choi, Y. L., Lim, S. M., Deng, S., Huang, D., Ozeck, M., et al. (2014). A single-tube multiplexed assay for detecting ALK, ROS1, and RET fusions in lung cancer. J. Mol. Diagn. 16, 229-243. doi: 10.1016/j.jmoldx.2013.11.007

Lovly, C. M., Gupta, A., Lipson, D., Otto, G., Brennan, T., Chung, C. T., et al. (2014). Inflammatory myofibroblastic tumors harbor multiple potentially actionable kinase fusions. Cancer Discov. 4, 889-895. doi: 10.1158/2159-8290. CD-14-0377

Lynch, T. J., Bell, D. W., Sordella, R., Gurubhagavatula, S., Okimoto, R. A., Brannigan, B. W., et al. (2004). Activating mutations in the epidermal growth factor receptor underlying responsiveness of non-small-cell lung cancer to gefitinib. N. Engl. J. Med. 350, 2129-2139. doi: 10.1056/NEJMoa040938

Ma, Z., Hill, D. A., Collins, M. H., Morris, S. W., Sumegi, J., Zhou, M., et al. (2003). Fusion of ALK to the Ran-binding protein 2 (RANBP2) gene in inflammatory myofibroblastic tumor. Genes Chromosomes Cancer 37, 98-105. doi: 10.1002/ gcc. 10177

Maesako, Y., Izumi, K., Okamori, S., Takeoka, K., Kishimori, C., Okumura, A., et al. (2014). inv(2)(p23q13)/RAN-binding protein 2 (RANBP2)-ALK fusion gene in myeloid leukemia that developed in an elderly woman. Int. J. Hematol. 99, 202-207. doi: 10.1007/s12185-013-1482-x

Majewski, I. J., Mittempergher, L., Davidson, N. M., Bosma, A., Willems, S. M., Horlings, H. M., et al. (2013). Identification of recurrent FGFR3 fusion genes in lung cancer through kinome-centred RNA sequencing. J. Pathol. 230, 270-276. doi: $10.1002 /$ path.4209

Marino-Enriquez, A., Ou, W. B., Weldon, C. B., Fletcher, J. A., and Perez-Atayde, A. R. (2011). ALK rearrangement in sickle cell trait-associated renal medullary carcinoma. Genes Chromosomes Cancer 50, 146-153. doi: 10.1002/gcc.20839

McFadden, D. G., Dias-Santagata, D., Sadow, P. M., Lynch, K. D., Lubitz, C., Donovan, S. E., et al. (2014). Identification of oncogenic mutations and gene fusions in the follicular variant of papillary thyroid carcinoma. J. Clin. Endocrinol. Metab. 99, E2457-E2462. doi: 10.1210/jc.2014-2611

Meech, S. J., McGavran, L., Odom, L. F., Liang, X., Meltesen, L., Gump, J., et al. (2001). Unusual childhood extramedullary hematologic malignancy with natural killer cell properties that contains tropomyosin 4-anaplastic lymphoma kinase gene fusion. Blood 98, 1209-1216. doi: 10.1182/blood.V98.4.1209

Mitelman, F. (2000). Recurrent chromosome aberrations in cancer. Mutat. Res. 462, 247-253. doi: 10.1016/S1383-5742(00)00006-5

Mitelman, F., Johansson, B., and Mertens, F. (2007). The impact of translocations and gene fusions on cancer causation. Nat. Rev. Cancer 7, 233-245. doi: 10. 1038/nrc2091

Morris, S. W., Kirstein, M. N., Valentine, M. B., Dittmer, K. G., Shapiro, D. N., Saltman, D. L., et al. (1994). Fusion of a kinase gene, ALK, to a nucleolar protein gene, NPM, in non-Hodgkin's lymphoma. Science 263, 1281-1284. doi: $10.1126 /$ science. 8122112

Nakata, T., Kitamura, Y., Shimizu, K., Tanaka, S., Fujimori, M., Yokoyama, S., et al. (1999). Fusion of a novel gene, ELKS, to RET due to translocation $\mathrm{t}(10 ; 12)(\mathrm{q} 11 ; \mathrm{p} 13)$ in a papillary thyroid carcinoma. Genes Chromosomes Cancer. 25, 97-103. doi: 10.1002/(SICI) 1098-2264(199906)25:2<97::AID-GCC4>3.0. $\mathrm{CO} ; 2-\mathrm{L}$

Nakaoku, T., Tsuta, K., Ichikawa, H., Shiraishi, K., Sakamoto, H., Enari, M., et al. (2014). Druggable oncogene fusions in invasive mucinous lung adenocarcinoma. Clin. Cancer Res. 20, 3087-3093. doi: 10.1158/1078-0432. CCR-14-0107 
Paez, J. G., Janne, P. A., Lee, J. C., Tracy, S., Greulich, H., Gabriel, S., et al. (2004). EGFR mutations in lung cancer: correlation with clinical response to gefitinib therapy. Science 304, 1497-1500. doi: 10.1126/science.1099314

Panagopoulos, I., Nilsson, T., Domanski, H. A., Isaksson, M., Lindblom, P., Mertens, F., et al. (2006). Fusion of the SEC31L1 and ALK genes in an inflammatory myofibroblastic tumor. Int. J. Cancer 118, 1181-1186. doi: 10. $1002 /$ ijc. 21490

Pao, W., Miller, V., Zakowski, M., Doherty, J., Politi, K., Sarkaria, I., et al. (2004). EGF receptor gene mutations are common in lung cancers from "never smokers" and are associated with sensitivity of tumors to gefitinib and erlotinib. Proc. Natl. Acad. Sci. U.S.A. 101, 13306-13311. doi: 10.1073/pnas.0405220101

Perot, G., Soubeyran, I., Ribeiro, A., Bonhomme, B., Savagner, F., BoutetBouzamondo, N., et al. (2014). Identification of a recurrent STRN/ALK fusion in thyroid carcinomas. PLoS One 9:e87170. doi: 10.1371/journal.pone.0087170

Ren, H., Tan, Z. P., Zhu, X., Crosby, K., Haack, H., Ren, J. M., et al. (2012). Identification of anaplastic lymphoma kinase as a potential therapeutic target in ovarian cancer. Cancer Res. 72, 3312-3323. doi: 10.1158/0008-5472.CAN11-3931

Rikova, K., Guo, A., Zeng, Q., Possemato, A., Yu, J., Haack, H., et al. (2007). Global survey of phosphotyrosine signaling identifies oncogenic kinases in lung cancer. Cell 131, 1190-1203. doi: 10.1016/j.cell.2007.11.025

Saenko, V., Rogounovitch, T., Shimizu-Yoshida, Y., Abrosimov, A., Lushnikov, E., Roumiantsev, P., et al. (2003). Novel tumorigenic rearrangement, $\Delta r f p / r e t$, in a papillary thyroid carcinoma from externally irradiated patient. Mutat. Res. 527, 81-90. doi: 10.1016/S0027-5107(03)00056-3

Sakamoto, K., Nakasone, H., Togashi, Y., Sakata, S., Tsuyama, N., and Baba, S. (2016). ALK-positive large B-cell lymphoma: identification of EML4-ALK and a review of the literature focusing on the ALK immunohistochemical staining pattern. Int. J. Hematol. 103, 399-408. doi: 10.1007/s12185-016-1934-1

Salassidis, K., Bruch, J., Zitzelsberger, H., Lengfelder, E., Kellerer, A. M., and Bauchinger, M. (2000). Translocation $\mathrm{t}(10 ; 14)$ (q11.2:q22.1) fusing the kinetin to the RET gene creates a novel rearranged form (PTC8) of the RET protooncogene in radiation-induced childhood papillary thyroid carcinoma. Cancer Res. 60, 2786-2789.

Seto, T., Kiura, K., Nishio, M., Nakagawa, K., Maemondo, M., Inoue, A., et al. (2013). CH5424802 (RO5424802) for patients with ALK-rearranged advanced non-small-cell lung cancer (AF-001JP study): a single-arm, open-label, phase 1-2 study. Lancet Oncol. 14, 590-598. doi: 10.1016/S1470-2045(13)70142-6

Shaw, A. T., Kim, D. W., Nakagawa, K., Seto, T., Crino, L., Ahn, M. J., et al. (2013). Crizotinib versus chemotherapy in advanced ALK-positive lung cancer. N. Engl. J. Med. 368, 2385-2394. doi: 10.1056/NEJMoa1214886

Shigematsu, H., Lin, L., Takahashi, T., Nomura, M., Suzuki, M., Wistuba, I. I., et al. (2005). Clinical and biological features associated with epidermal growth factor receptor gene mutations in lung cancers. J. Natl. Cancer Inst. 97, 339-346. doi: $10.1093 /$ jnci/dji055

Shiota, M., Fujimoto, J., Semba, T., Satoh, H., Yamamoto, T., and Mori, S. (1994). Hyperphosphorylation of a novel $80 \mathrm{kDa}$ protein-tyrosine kinase similar to Ltk in a human Ki-1 lymphoma cell line, AMS3. Oncogene 9, 1567-1574.

Soda, M., Choi, Y. L., Enomoto, M., Takada, S., Yamashita, Y., Ishikawa, S., et al. (2007). Identification of the transforming EML4-ALK fusion gene in non-small-cell lung cancer. Nature 448, 561-566. doi: 10.1038/nature05945

Song, Z., Yu, X., and Zhang, Y. (2017). Clinicopathological characteristics and survival of ALK, ROS1 and RET rearrangements in non-adenocarcinoma nonsmall cell lung cancer patients. Cancer Biol. Ther. 18, 883-887. doi: 10.1080/ 15384047.2016.1235660

Stransky, N., Cerami, E., Schalm, S., Kim, J. L., and Lengauer, C. (2014). The landscape of kinase fusions in cancer. Nat. Commun. 5:4846. doi: 10.1038/ ncomms 5846

Sugawara, E., Togashi, Y., Kuroda, N., Sakata, S., Hatano, S., Asaka, R., et al. (2012). Identification of anaplastic lymphoma kinase fusions in renal cancer: largescale immunohistochemical screening by the intercalated antibody-enhanced polymer method. Cancer 118, 4427-4436. doi: 10.1002/cncr.27391

Takahashi, M., Ritz, J., and Cooper, G. M. (1985). Activation of a novel human transforming gene, ret, by DNA rearrangement. Cell 42, 581-588. doi: 10.1016/ 0092-8674(85)90115-1

Takeuchi, K., Choi, Y. L., Togashi, Y., Soda, M., Hatano, S., Inamura, K., et al. (2009). KIF5B-ALK, a novel fusion oncokinase identified by an immunohistochemistry-based diagnostic system for ALK-positive lung cancer. Clin. Cancer Res. 15, 3143-3149. doi: 10.1158/1078-0432.CCR-08-3248
Takeuchi, K., Soda, M., Togashi, Y., Ota, Y., Sekiguchi, Y., Hatano, S., et al. (2011). Identification of a novel fusion, SQSTM1-ALK, in ALK-positive large B-cell lymphoma. Haematologica 96, 464-467. doi: 10.3324/haematol.2010.033514

Takeuchi, K., Soda, M., Togashi, Y., Suzuki, R., Sakata, S., Hatano, S., et al. (2012). RET, ROS1 and ALK fusions in lung cancer. Nat. Med. 18, 378-381. doi: 10. $1038 / \mathrm{nm} .2658$

Takeuchi, K., Togashi, Y., Kamihara, Y., Fukuyama, T., Yoshioka, H., Inoue, A., et al. (2016). Prospective and clinical validation of ALK immunohistochemistry: results from the phase I/II study of alectinib for ALK-positive lung cancer (AF-001JP study). Ann. Oncol. 27, 185-192. doi: 10.1093/annonc/mdv501

Tan, D. S.-W., Kim, D.-W., Thomas, M., Pantano, S., Wang, Y., Szpakowski, S. L., et al. (2016). Genetic landscape of ALK+ non-small cell lung cancer (NSCLC) patients (pts) and response to ceritinib in ASCEND-1. J. Clin. Oncol. 34(15 Suppl.), 9064-9064. doi: 10.1200/JCO.2016.34.15_suppl.9064

Togashi, Y., Soda, M., Sakata, S., Sugawara, E., Hatano, S., Asaka, R., et al. (2012). KLC1-ALK: a novel fusion in lung cancer identified using a formalin-fixed paraffin-embedded tissue only. PLoS One 7:e31323. doi: 10.1371/journal.pone. 0031323

Tort, F., Pinyol, M., Pulford, K., Roncador, G., Hernandez, L., Nayach, I., et al. (2001). Molecular characterization of a new ALK translocation involving moesin (MSN-ALK) in anaplastic large cell lymphoma. Lab. Invest. 81, 419-426. doi: 10.1038/labinvest.3780249

Touriol, C., Greenland, C., Lamant, L., Pulford, K., Bernard, F., Rousset, T., et al. (2000). Further demonstration of the diversity of chromosomal changes involving 2p23 in ALK-positive lymphoma: 2 cases expressing ALK kinase fused to CLTCL (clathrin chain polypeptide-like). Blood 95, 3204-3207.

Tsuta, K., Kohno, T., Yoshida, A., Shimada, Y., Asamura, H., Furuta, K., et al. (2014). RET-rearranged non-small-cell lung carcinoma: a clinicopathological and molecular analysis. Br. J. Cancer 110, 1571-1578. doi: 10.1038/bjc.2014.36

Tsuyama, N., Sakamoto, K., Sakata, S., Dobashi, A., and Takeuchi, K. (2017). Anaplastic large cell lymphoma: pathology, genetics, and clinical aspects. J. Clin. Exp. Hematop. 57, 120-142. doi: 10.3960/jslrt.17023

Van Roosbroeck, K., Cools, J., Dierickx, D., Thomas, J., Vandenberghe, P., Stul, M., et al. (2010). ALK-positive large B-cell lymphomas with cryptic SEC31A-ALK and NPM1-ALK fusions. Haematologica 95, 509-513. doi: 10.3324/haematol. 2009.014761

Velcheti, V., Madison, R., Ali, S. M., and Schrock, A. B. (2018). WAC/RET: a novel RET oncogenic fusion variant in non-small cell lung carcinoma. J. Thorac. Oncol. 13, e122-e123. doi: 10.1016/j.jtho.2018.03.003

Velcheti, V., Thawani, R., Khunger, M., Mukhopadhyay, S., Chute, D. J., Schrock, A. B., et al. (2017). FRMD4A/RET: a novel RET oncogenic fusion variant in non-small cell lung carcinoma. J. Thorac. Oncol. 12, e15-e16. doi: 10.1016/j. jtho.2016.11.274

Wang, R., Hu, H., Pan, Y., Li, Y., Ye, T., Li, C., et al. (2012). RET fusions define a unique molecular and clinicopathologic subtype of non-small-cell lung cancer. J. Clin. Oncol. 30, 4352-4359. doi: 10.1200/JCO.2012.44.1477

Weinstein, I. B. (2002). Cancer. Addiction to oncogenes-the Achilles heal of cancer. Science 297, 63-64. doi: 10.1126/science.1073096

Yakirevich, E., Resnick, M. B., Mangray, S., Wheeler, M., Jackson, C. L., Lombardoet, K. A., et al. (2016). Oncogenic ALK fusion in rare and aggressive subtype of colorectal adenocarcinoma as a potential therapeutic target. Clin. Cancer Res. 22, 3831-3840. doi: 10.1158/1078-0432.CCR-15-3000

Zhang, X., Li, Y., Liu, C., Wang, W., Li, M., Lv, D., et al. (2018). Identification of a novel KIF13A-RET fusion in lung adenocarcinoma by next-generation sequencing. Lung Cancer 118, 27-29. doi: 10.1016/j.lungcan.2017.08.019

Zheng, Z., Liebers, M., Zhelyazkova, B., Cao, Y., Panditi, D., Lynch, K. D., et al. (2014). Anchored multiplex PCR for targeted next-generation sequencing. Nat. Med. 20, 1479-1484. doi: 10.1038/nm.3729

Conflict of Interest Statement: The author declares that the research was conducted in the absence of any commercial or financial relationships that could be construed as a potential conflict of interest.

Copyright (C) 2019 Takeuchi. This is an open-access article distributed under the terms of the Creative Commons Attribution License (CC BY). The use, distribution or reproduction in other forums is permitted, provided the original author(s) and the copyright owner(s) are credited and that the original publication in this journal is cited, in accordance with accepted academic practice. No use, distribution or reproduction is permitted which does not comply with these terms. 